Henriksen, N. \& Jepsen, H. F. 1985: Precambrian crystalline basement at the head of Victoria Fjord, North Greenland. Rapp. Grønlands geol. Unders. 126, 11-16.

Higgins, A. K., Friderichsen, J. D. \& Soper, N. J. 1981: The North Greenland fold belt between central Johannes V. Jensen Land and eastern Nansen Land. Rapp. Grønlands geol. Unders. 106, 35-45.

Hurst, J. M. 1980: Silurian stratigraphy and facies distribution in Washington Land and western Hall Land, North Greenland. Bull. Grønlands geol. Unders. 138, 95 pp.

Jakobsen, U. H. \& Steenfelt, A. 1985: Zinc mineralisation at Navarana Fjord, central North Greenland. Rapp. Grønlands geol. Unders. 126, 105-109.

Larsen, P.-H. \& Escher, J. C. 1985: The Silurian turbidite sequence of the Peary Land Group between Newman Bugt and Victoria Fjord, western North Greenland. Rapp. Grønlands geol. Unders. 126, $47-67$.

Peel, J. S. \& Wright, S. C. 1985: Cambrian platform stratigraphy in the Warming Land - Freuchen Land region, North Greenland. Rapp. Grønlands geol. Unders. 126, 17-24.

Soper, N. J. \& Higgins, A. K. 1985: Thin-skinned structures at the basin-shelf transition in North Greenland. Rapp. Grønlands geol. Unders. 126, 87-94.

Steenfelt, A. 1985: Reconnaissance scale geochemical survey in central and western North Greenland. Preliminary results concerning zinc and barium. Rapp. Grønlands geol. Unders. 126, 95-104.

\title{
Source rock investigations and shallow core drilling in central and western North Greenland - project 'Nordolie'
}

\author{
F. G. Christiansen, O. Nykjær and H. Nøhr-Hansen
}

The aim of project 'Nordolie' (Christiansen \& Rolle, 1985) is to study the distribution and maturity of potential hydrocarbon source rocks in central and western North Greenland.

A first broad reconnaissance and examination of most lithostratigraphic units throughout the region in 1984, followed by organic geochemical and palynofacies analyses, showed that some intervals in the Cambrian shelf sequence and in the Cambrian to Silurian trough sequence are sufficiently rich in organic matter to be considered as potential source rocks (Christiansen et al., 1985). The Cambrian and Ordovician trough sequence is thermally postmature with respect to hydrocarbon generation in the whole area. Consequently the second and final field programme within the project (1985) concentrated on the Cambrian shelf sequence (especially the Henson Gletscher Formation in the Brønlund Fjord Group) and the Silurian slope to trough sequence (Lafayette Bugt Formation and Wulff Land Formation).

The main purpose of the 1985 work was to make a detailed study of these units combining field work and shallow core drilling. The samples and cores provide the basis for later detailed maturity studies and a quantitative evaluation of source rock quality and volume. As in 1984 , the 1985 field season was fully integrated with the geological mapping programme in the region (Henriksen, this report).

The field work was carried out by a team of two geologists and a drilling team with three technicians (John Boserup, Anders Clausen, Jørgen Bojesen-Koefoed) and a drill site geologist. The three geologists alternated often in order to obtain continuity in the programme and furthermore six of the total 14 camps were located at the drill sites (fig. 1). 


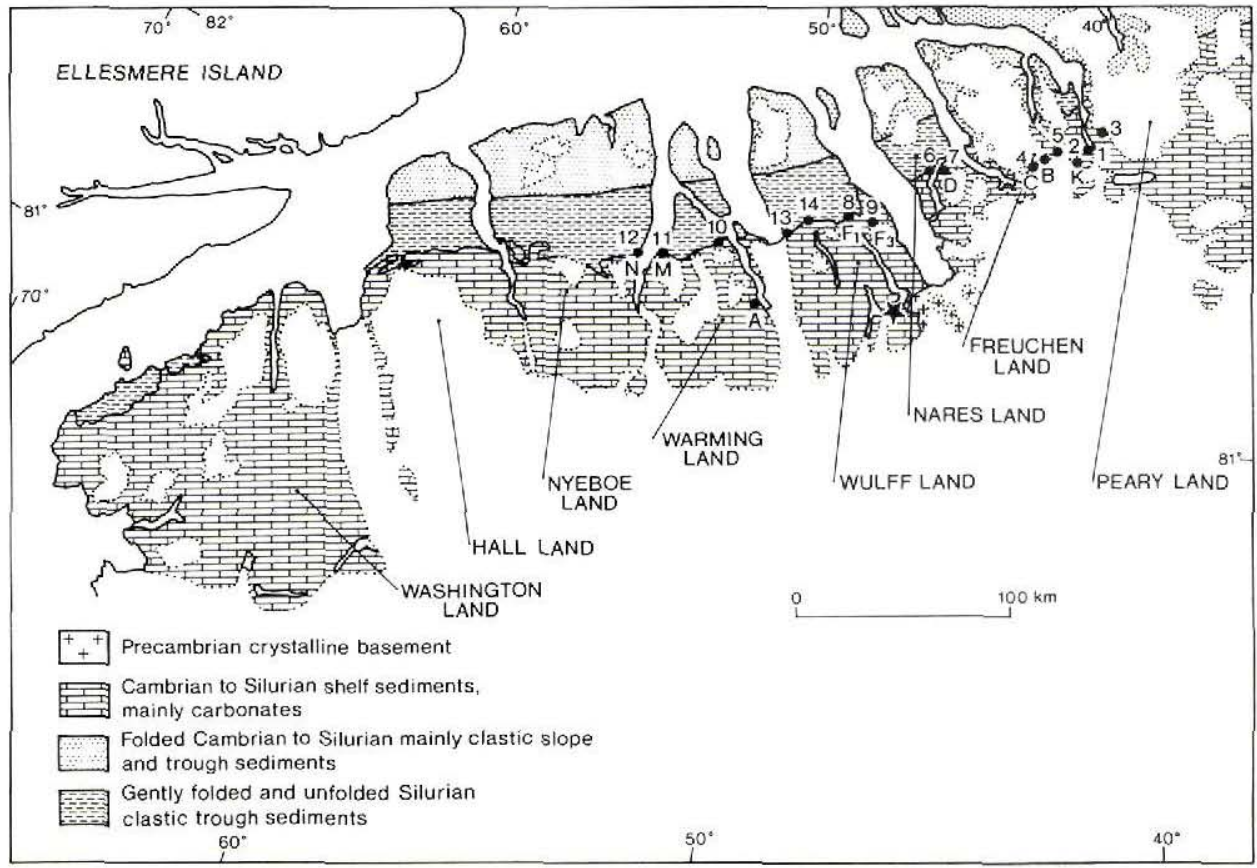

Fig. 1. Camps (numbers) and drill sites (letters) during the 1985 field season. The oil seep is indicated with a star. Based on Dawes (1976).

\section{The drilling programme}

The drilling unit (fig. 2) was assembled by J. Boserup and A. Clausen at the Geological Survey of Greenland and had previously been employed in Jameson Land (Surlyk, 1983; Surlyk et al., 1984). With a Bell Jet Ranger helicopter four sling loads and four cabin loads are usually necessary to move the drill and camp equipment plus four persons (total c. 2000 $\mathrm{kg}$ ). Long distance camp moves were often performed by combined Twin Otter - helicopter operations.

Thirteen holes were drilled to various depths, e.g. a maximum $40 \mathrm{~m}$ (Tables 1 and 2). Approximately $345 \mathrm{~m}$ were drilled and except for the uppermost metres in the active layer or overburden the recovery was almost $100 \%$. All cores are described at the drill site on a scale 1:50 or 1:100 and most holes were logged by gamma ray. These values show good correlation with hand measured gamma ray logs of nearby exposures.

There were some limitations in the choice of drill sites, especially in the Henson Gletscher Formation. Many of the shaly source rocks can only be reached after penetration of thick overburden or cliff-forming beds of dolomite conglomerate. The need for continuous water supply and helicopter landing sites excluded the use of some well-exposed geological sections.

The first hole (A), located a few kilometres north of the base camp, was drilled mainly to test the equipment under the strong permafrost conditions, and the cored Ordovician dolomites are expected to have a very low content of organic matter. The five following holes 


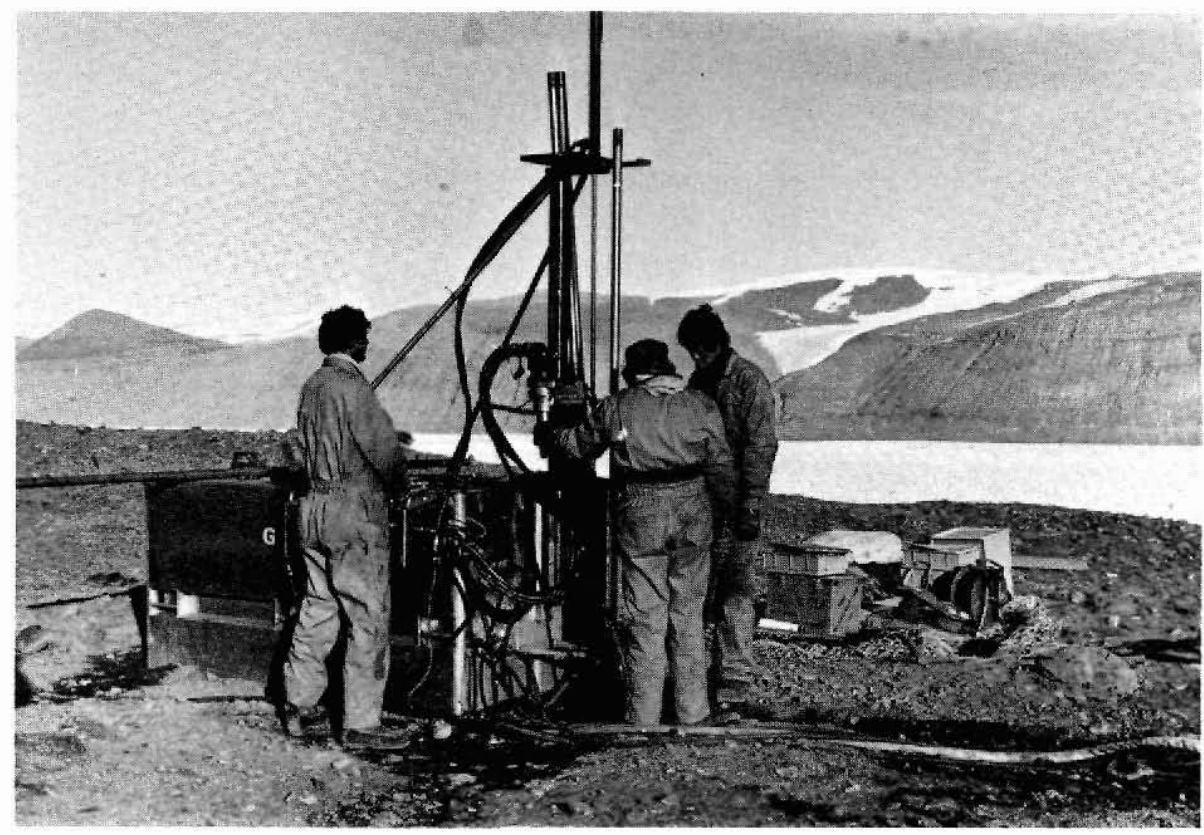

Fig. 2. Drilling on the N1 site.

( $\mathrm{K}, \mathrm{C} 1, \mathrm{C} 2, \mathrm{~B} 1$ and $\mathrm{B} 2$ ) at three localities were all drilled in the Cambrian sequence (Table 1). The greenish shale from the Buen Formation at $K$ is not of source rock quality. The four holes in the Henson Gletscher Formation are very interesting. C2 penetrates most of the lower sequence of dolomite and lime mudstone which is considered to be the best Cambrian source rock in the area. $\mathrm{C} 1, \mathrm{~B} 1$ and $\mathrm{B} 2$ are from the middle and upper part of the formation with bitumen impregnated sandstone and dolomite.

The last seven holes are in slope facies shales outcropping along the Silurian shelf/trough margin (Table 1). D penetrates the lower organic-rich part of the Thors Fjord Member and F2 and N2 are from the most organic-rich part of the Lafayette Bugt Formation. F1 is from interlayered limestone, conglomerate and shale of the Lafayette Bugt Formation where it onlaps the carbonate shelf sequence. F3 and N1 represent the thicker but less organic-rich shales and siltstones of the Wulff Land Formation.

The drilling programme was accomplished as scheduled despite major technical challenges. The main engine seized at the second locality because of a factory defect, and the programme was delayed one week. The strong permafrost created serious problems and many metres of drill rods were lost. Temperature measurements in five of the holes show that the freezing point is reached 20 to 40 minutes after termination of hot water circulation and the temperature stabilizes between $-11^{\circ} \mathrm{C}$ and $-14^{\circ} \mathrm{C}$ within a couple of days (Table 2).

\section{Henson Gletscher Formation}

The Henson Gletscher Formation (Ineson \& Peel, in press) is exposed in the southern part of Freuchen Land and in the south-eastern part of Peary Land (fig. 1). In addition to the four drill holes in the formation, 16 more or less complete sections have been sampled. The total thickness varies between 40 and more than $150 \mathrm{~m}$ and the formation can be divided into 
Table 1. Geological description of the different drill sites

\begin{tabular}{|c|c|c|c|c|}
\hline \multicolumn{2}{|c|}{ Drill site } & \multirow{4}{*}{$\begin{array}{l}\text { Region } \\
\text { Warming Land } \\
\text { Freuchen land } \\
\text { Freuchen land }\end{array}$} & \multirow{2}{*}{$\begin{array}{l}\text { Lithostratigraphy } \\
\text { Steensby Gletscher Fm }\end{array}$} & \multirow{2}{*}{$\begin{array}{l}\text { Main lithology } \\
\text { Dolomite }\end{array}$} \\
\hline A & 318001 & & & \\
\hline $\mathrm{K}$ & 318002 & & Upper Buen Fm & Green shale \\
\hline$C_{1}^{*}$ & 318003 & & $\begin{array}{l}\text { Base Sydpasset Fm } \\
\text { Upper Henson Glet. Fm }\end{array}$ & $\begin{array}{l}\text { Dolomite grainstone } \\
\text { and conglomerate }\end{array}$ \\
\hline $\mathrm{C}_{2}^{*}$ & 318004 & Freuchen Land & $\begin{array}{l}\text { Lower Henson Glet. Fm } \\
\text { Top Aftenstjernesø Fm }\end{array}$ & $\begin{array}{l}\text { Lime and dolomite } \\
\text { mudstone }\end{array}$ \\
\hline$B_{1}$ & 318005 & Freuchen Land & Upper Henson Glet. Fm & $\begin{array}{l}\text { Limestone and } \\
\text { sandstone }\end{array}$ \\
\hline $\mathbf{B}_{2}$ & 318006 & Freuchen Land & Upper Henson Glet. Fm & $\begin{array}{l}\text { Limestone and } \\
\text { sandstone }\end{array}$ \\
\hline D & 318007 & Nares Land & $\begin{array}{l}\text { Thors Fjord Mb } \\
\text { Top Aleqatsiaq Fjord Fm }\end{array}$ & Black shale \\
\hline $\mathbf{F}_{1}$ & 318008 & Wulff Land & $\begin{array}{l}\text { Lower Lafayette Bugt Fm } \\
\text { Top Aleqatsiaq Fjord Fm }\end{array}$ & $\begin{array}{l}\text { Black limestone } \\
\text { and shale }\end{array}$ \\
\hline $\mathrm{F}_{2}$ & 318009 & Wulff Land & Lafayette Bugt Fm & Black shale \\
\hline $\mathrm{F}_{3}$ & 318010 & Wulff Land & Wulff Land Fm & Silty shale \\
\hline $\mathbf{M}^{3}$ & 318011 & Warming Land & $\begin{array}{l}\text { Undiff. Quaternary } \\
\text { (Lafayette Bugt Fm) }\end{array}$ & Gravel \\
\hline $\begin{array}{l}\mathbf{N}_{1} \\
\mathbf{N}_{2}\end{array}$ & $\begin{array}{l}318012 \\
318013\end{array}$ & $\begin{array}{l}\text { Nyeboe Land } \\
\text { Nyeboe Land }\end{array}$ & $\begin{array}{l}\text { Wulff Land Fm } \\
\text { Lafayette Bugt Fm }\end{array}$ & $\begin{array}{l}\text { Silty shale } \\
\text { Black shale and } \\
\text { limestone }\end{array}$ \\
\hline
\end{tabular}

three main depositional facies: a lower carbonate sequence, a central clastic sequence, and an upper carbonate sequence. The lower carbonate sequence has good source rock intervals throughout the area whereas the upper carbonates are only occasionally rich in organic matter. The clastic sequence and the upper carbonates are potential reservoirs and migration conduits with a close spatial relation to the source rocks. The common presence of bitumenimpregnated sandstones and bitumen-filled vugs and veins of dolospar in the carbonates (fig. 3) suggests that significant hydrocarbon generation has already occurred, and that most areas might be mature to postmature.

Table 2. Technical details of the drilling at each site

\begin{tabular}{|c|c|c|c|c|c|}
\hline Drill & site & Period & Depth (m) & Drill time & Temp/depth \\
\hline A & 318001 & $27.6-1.7$ & 28.70 & $\sim 121 / 2 \mathrm{~h}$ & - \\
\hline $\mathbf{K}$ & 318002 & $1.7-6.7$ & 19.61 & $\sim 81 / 2 \mathrm{~h}$ & - \\
\hline $\mathrm{C}_{1}^{*}$ & 318003 & $6.7-15.7$ & 23.90 & $\sim 151 / 2 h$ & - \\
\hline $\mathrm{C}_{2}^{*}$ & 318004 & $15.7-18.7$ & 34.80 & $\sim 15^{1 / 2} h$ & $<-10^{\circ} \mathrm{C} / 10 \mathrm{~m}$ \\
\hline $\mathrm{B}_{1}^{2}$ & 318005 & $18.7-21.7$ & 11.78 & $\sim 10 \mathrm{~h}$ & - \\
\hline$B_{2}$ & 318006 & $21.7-24.7$ & 12.03 & $\sim 5 h$ & - \\
\hline $\mathrm{D}^{2}$ & 318007 & $24.7-27.7$ & 39.66 & $\sim 131 / 2 h$ & - \\
\hline$F_{1}$ & 318008 & $27.7-30.7$ & 30.90 & $-101 / 2 h$ & $-14^{\circ} \mathrm{C} / 29$ \\
\hline $\mathrm{F}_{2}$ & 318009 & $30.7-2.8$ & 39.71 & $\sim 10^{1 / 2} h$ & - \\
\hline $\mathrm{F}_{3}$ & 318010 & $2.8-7.8$ & 30.38 & $\sim 13 \mathrm{~h}$ & $-11^{\circ} \mathrm{C} / 15$ \\
\hline M & 318011 & $7.8-9.8$ & 5.71 & $\sim 7 h$ & - \\
\hline $\mathrm{N}_{1}$ & 318012 & $9.8-13.8$ & 28.87 & $\sim 14 \mathrm{~h}$ & $-14^{\circ} \mathrm{C} / 12$ \\
\hline $\mathrm{N}_{2}$ & 318013 & $13.8-17.8$ & 40.02 & $\sim 13 \mathrm{~h}$ & $-13^{\circ} \mathrm{C} / 20$ \\
\hline
\end{tabular}




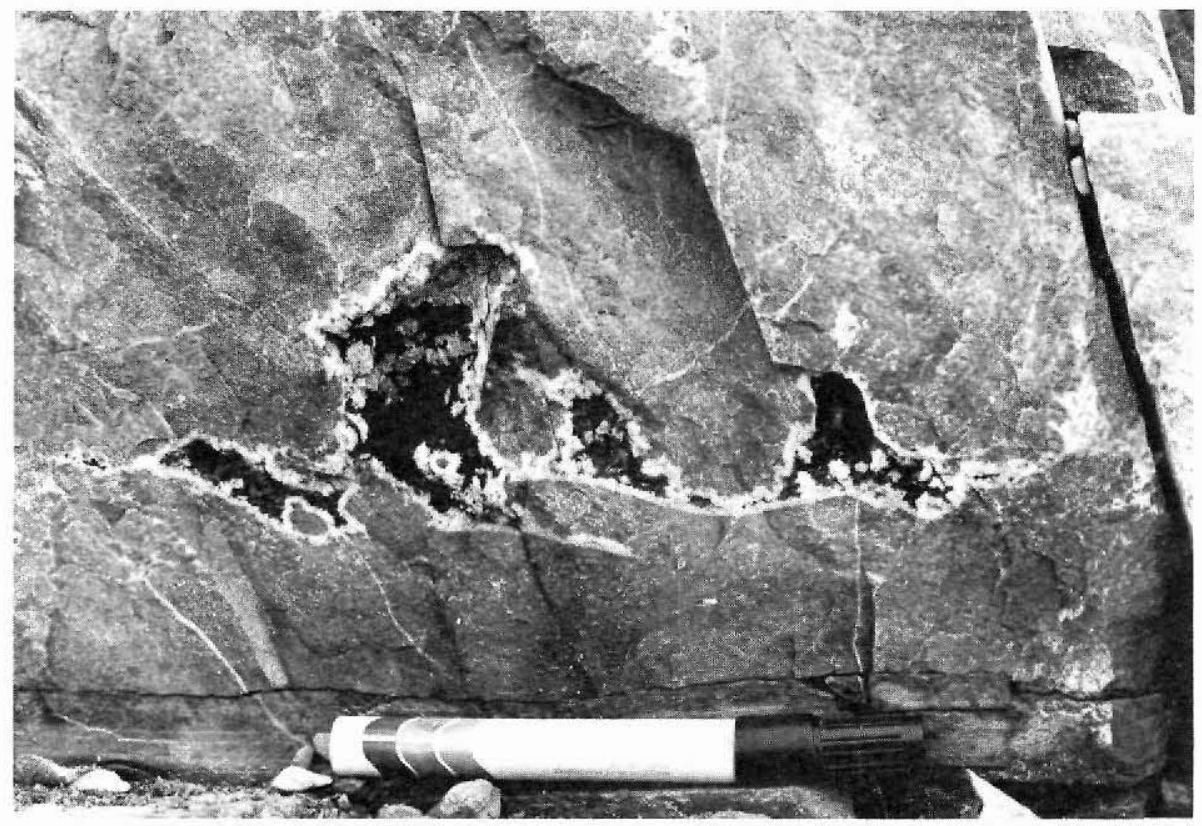

Fig. 3. Bitumen filled dolospar vugs and veins in a dolomite grainstone at the $\mathrm{Cl}$ drillsite.

\section{Lafayette Bugt Formation and Wulff Land Formation}

The Lafayette Bugt Formation and the Wulff Land Formation (Hurst \& Surlyk, 1982) which outcrop along the Silurian shelf/trough margin, have been examined from Hall Land in the south-west to Freuchen Land in the north-east. Organic-rich shale and lime mudstone are common in this zone but both the facies development and the thickness are highly variable. In addition to the seven drill holes through these slope shales, more than 20 sections have been studied in detail. The organic rich shales have been traced and sampled with a close spacing in a longitudinal profile along the margin in order to refine the maturity study presented by Christiansen et al. (1985).

In many places in the region there is evidence of hydrocarbon generation in the sequence. Impressive bitumen fillings have been observed in calcirudite (coral fragments) and in corals in shaly debris flow in Wulff Land, Warming Land and Nyeboe Land. Black coatings and fracture fillings of presumed bituminous origin are common in many calcarenites and calcirudites.

\section{Seep in Portfjeld Formation breccia}

The impressive seep (fig. 4), discovered earlier this summer by H. F. Jepsen and J. B. Jørgensen, was visited late in the season. Bitumen-impregnated sandstone and dolomite from the Buen Formation and the Ryder Gletscher Group have previously been mentioned in southern Wulff and Warming Land (Christiansen et al., 1985) but no potential source rock is known to occur horizontally closer than $50 \mathrm{~km}$ away. 


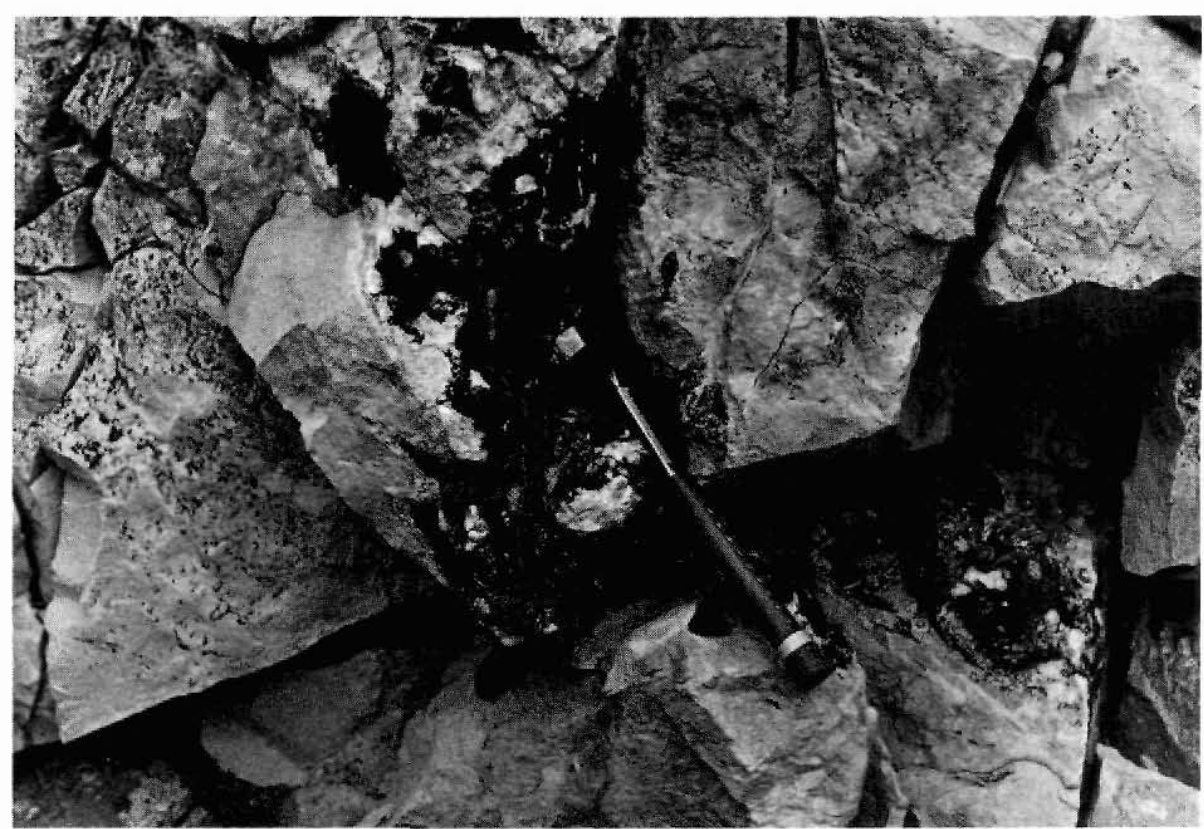

Fig. 4. Seepage of asphaltic material from veins and cracks in dolomite. See fig. 1 for location.

The tar or asphaltic material in the seep shows evidence of flow, supposedly on hot summer days. It is related to cracks and veins of dolospar in a large algal laminated dolomite block in the Portfjeld breccia, which is situated less than $100 \mathrm{~m}$ above the contact to the basement gneisses.

The occurrence of the seep can be interpreted either as staining from a large scale migration to a now eroded reservoir, as tar along the margin of a postmature basin, or alternatively as evidence of oil trapped stratigraphically by a tar seal (Moore, 1984).

Preliminary geochemical analysis with gas chromatography and mass spectrometry (P. Østfeldt, personal communication, 1985) shows that the material is strongly degraded by evaporation and bacterial activity. There is, however, no evidence of thermal alteration.

\section{Laboratory studies}

The main objective of the planned laboratory programme is to obtain data for detailed modelling of both the present and the past generation potential of the Cambrian and the Silurian source rock sequences. The preliminary maturity variation given by Christiansen et al. (1985) will be refined by closer spacing of analysed samples and by more sophisticated methods (gas chromatography, mass spectrometry, isotopic composition). Quantitative aspects of hydrocarbon generation will be studied using unweathered and statistically representative material from the cores. Priority will also be given to a study of the bitumen and asphaltic material. The types of bitumen which occur close to known source rocks and the widespread bitumen staining or seepage in the southern part of the region will be compared. 
Acknowledgements. The 'Nordolie' project is supported by the Danish Ministry of Energy through project no. EFP 83-2251-305. J. Bojesen-Koefoed, J. Boserup and A. Clausen are thanked for assistance in the field. B. Larsen and B. Sikker Hansen assisted with the preparation of the manuscript.

\section{References}

Christiansen, F. G., Nøhr-Hansen, H., Rolle, F. \& Wrang, P. 1985: Preliminary analysis of the hydrocarbon source rock potential of central and western North Greenland. Rapp. Grønlands geol. Unders. 126, 109-120.

Christiansen, F. G. \& Rolle, F. 1985: Project 'Nordolie': hydrocarbon source rock investigations in central North Greenland. Rapp. Grønlands geol. Unders. 125, 17-21.

Dawes, P. R. 1976: Precambrian to Tertiary of northern Greenland. In Escher, A. \& Watt, W. S. (edit.) Geology of Greenland, 248-303. Copenhagen: Geol. Surv. Greenland.

Hurst, J. M. \& Surlyk, F. 1982: Stratigraphy of the Silurian turbidite sequence of North Greenland. Bull. Grønlands geol. Unders. 145, 121 pp.

Ineson, J. R. \& Peel, J. S. in press: Cambrian shelf stratigraphy of the Peary Land region, central North Greenland. Bull. Grønlands geol. Unders.

Moore, L. V. 1984: Significance, classification of asphaltic material in petroleum exploration. Oil Gas J. 82(41), 109-112.

Surlyk, F. 1983: Source rock sampling, stratigraphical and sedimentological studies in the Upper Palaeozoic of the Jameson Land basin, East Greenland. Rapp. Grønlands geol. Unders. 115, 88-93.

Surlyk, F., Hurst, J. M., Marcussen, C., Piasecki, S., Rolle, F., Scholle, P. A., Stemmerik, L. \& Thomsen, E. 1984: Oil geological studies in the Jameson Land basin, East Greenland. Rapp. Grønlands geol. Unders. 120, $85-90$ 